\title{
THE ANNUAL BALANCE OF NORTH CASCADE GLACIERS, WASHINGTON, U.S.A., MEASURED AND PREDICTED USING AN ACTIVITY-INDEX METHOD
}

\author{
By Mauri S. Pelto \\ (Institute for Quaternary Studies and Department of Geological Sciences, \\ University of Maine, Orono, Maine 04469, and Foundation for Glacier and Environmental \\ Research, Seattle, Washington 98109, U.S.A.)
}

ABSTRACT. The annual balance has been measured for ten North Cascade glaciers in 1983-84, 1984-85, 1985-86, and 1986-87 (1984, 1985, 1986, and 1987). Based on these data, an annual balance prediction method was designed and tested. Comparison of measured versus predicted annual balances indicates an accuracy of $\pm 0.22-0.30 \mathrm{~m}$. The method is based on annual measurement of the accumulation area ratio (AAR), and determination of the perennially constant activity index and area-altitude distribution on each glacier. The accumulation area ratio is determined from aerial and ground photographs at the end of the ablation season. The activity index is identified from observation of the rise of the snow line with time, compared to measured snow depths above the snow line. The AAR-activity index method was used to calculate the annual balance of 47 North Cascade glaciers in 1984, 1985, 1986, and 1987. The mean balance during the 4 year period was $-0.33 \mathrm{~m}$.

From the mass-balance records, it is apparent that North Cascade glaciers can be divided into six climatic sensitivity groups. Each glacier type responds differently to specific climatic conditions. The mass-balance variation for glaciers of the same type is small.

Since 1977, warmer, drier climatic conditions have prevailed in the North Cascades, resulting in the retreat of 42 of the 47 glaciers examined.

\section{INTRODUCTION}

The North Cascades of Washington extend from Snoqualmie Pass to the Canadian border, an area of 20000 $\mathrm{km}^{2}$ (Fig. 1). There are 756 glaciers with a total area of $267 \mathrm{~km}^{2}$ in the North Cascades (Post and others, 1971). Glaciers for the purpose of this study are defined as perennial bodies of snow and/or ice with an area of at least $0.1 \mathrm{~km}^{2}$. All of the North Cascade glaciers are temperate and non-surging.

The North Cascades exhibit a system of peaks and ridges separated by deep glaciated valleys. Valley floors are between 600 and $1000 \mathrm{~m}$ a.s.1. Ridge crests are from 1900 to $2700 \mathrm{~m}$ a.s.1. With the exception of the North Cascade divide, most of the ridges trend nearly east-west. The region is densely forested up to $1400 \mathrm{~m}$. The tree line, which varies from 1500 to $2100 \mathrm{~m}$, is commonly above the accumulation zone of the glaciers. This is an indication of the strongly maritime climate of the North Cascades.

The weather of the North Cascades is controlled by the atmospheric pressure distribution over the north-east Pacific Ocean. From October until May, the weather of Washington is dependent on the position and relative strength of the Aleutian Low and Pacific High (Yarnal, 1984). The Aleutian Low strengthens and moves south during the fall. Simultaneously, the Pacific High weakens and shifts south. The result is a south-westerly to westerly air flow across the region. Embedded in this flow are cyclonic disturbances originating over the north-east Pacific Ocean that are the primary precipitation source for the North Cascades (Yarnal, 1984). The heaviest precipitation occurs in the months of October-December. In the spring, the Aleutian Low moves north-west and weakens. The Pacific High expands and strengthens, causing a west to north-west flow of generally dry stable air from the Pacific high-pressure region. July-September is noted for a lack of precipitation. The changing influence of the Aleutian Low is apparent in the cloud-cover decrease from $75 \%$ during the winter to $30 \%$ during the spring (Tangborn, 1980).

Annual precipitation varies from 2.0 to $4.0 \mathrm{~m}$ on the west side of the range and from 1.0 to $2.0 \mathrm{~m}$ on the east or dry side of the range. Annual temperatures are moderated by the strong maritime air flow. The mean annual temperature at the glaciation threshold ranges from $0.0^{\circ}$ to $2.0^{\circ} \mathrm{C}$, decreasing with increasing distance from the ocean (Porter, 1977).

The United States Geological Survey (USGS) has monitored the mass balance of South Cascade Glacier since 1955. The extensive hydrologic and mass-balance measurements have greatly increased the understanding of glacier hydrology, the annual variation of mass balance, and of the climatic parameters controlling mass balance on North Cascade glaciers (Meier and Tangborn, 1965: Tangborn and others, 1975; Tangborn, 1980). North Cascade glaciers fall into several different categories based on their sensitivity to specific climatic conditions. South Cascade Glacier is representative of only one climatic sensitivity group. Thus, no quantitative climatic or hydrologic conclusions can be drawn for the bulk of North Cascade glaciers, based on data from South Cascade Glacier alone. For this reason, the Foundation for Glacier and Environmental Research (FGER) in 1984 founded the North Cascade Glacier-Climate Project. The North Cascade Glacier-Climate Project has established a system for annually monitoring the annual balance and terminus activity of 47 North Cascade glaciers. The annual balance of ten glaciers is directly measured. Based on these data, an annual-balance prediction model was developed, tested, and used to calculate the annual balance of the remaining 37 glaciers under investigation.

\section{ANNUAL-BALANCE METHODS}

The goal of the North Cascade Glacier-Climate Project is to determine the annual balance with reasonable accuracy on numerous glaciers, rather than strict accuracy to a few. Mass-balance measurements are conducted during the later part of each ablation season. Thus, only annual balance is measured; winter and summer balances are not considered in this analysis.

Only accumulation measurements are made above the snow line in the accumulation zone. In the accumulation 


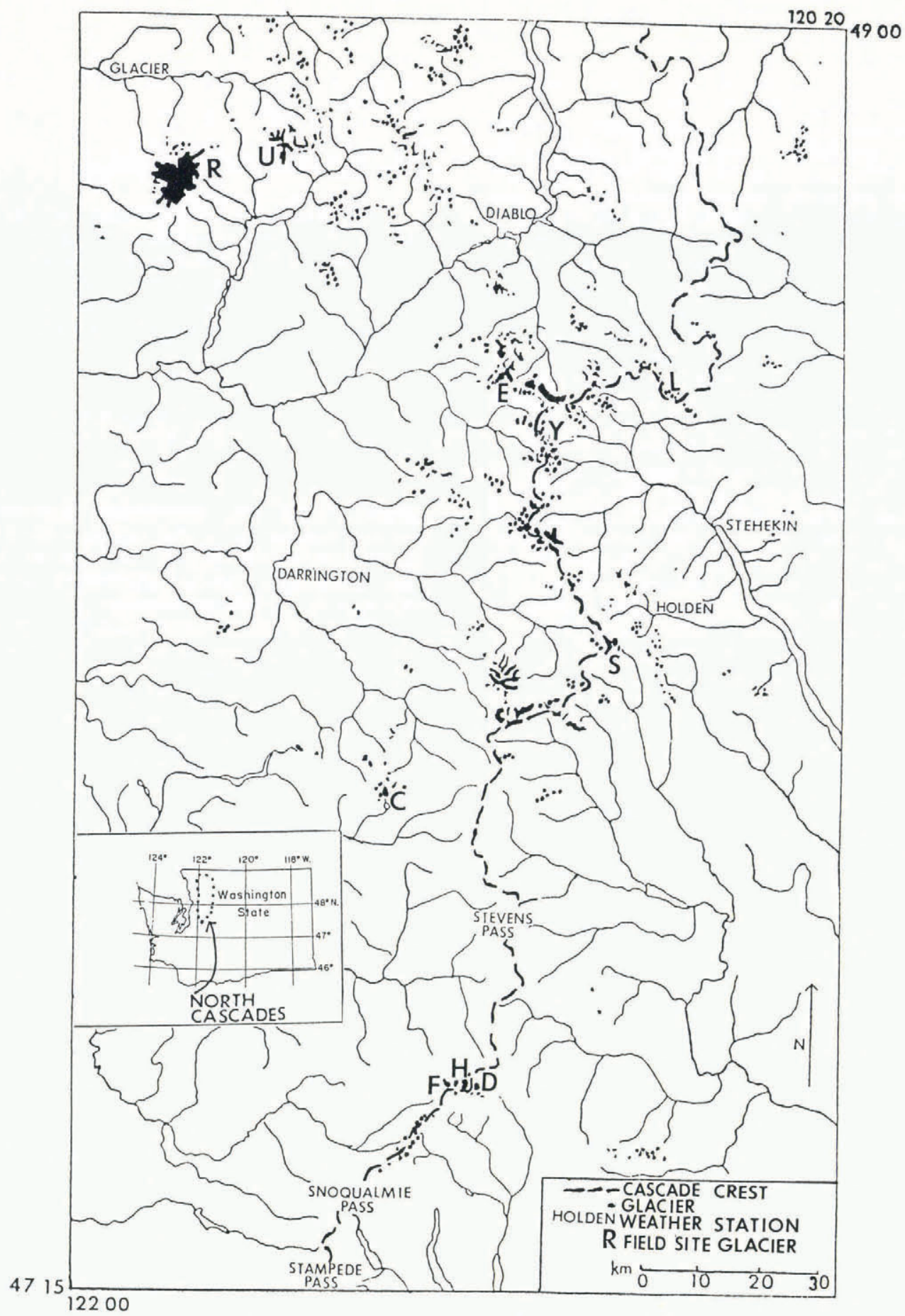

Fig. 1. Map of the North Cascade Range of Washington, showing location of glaciers and weather stations. Glaciers where annual-balance measurements are made are denoted by capital letters: $C$, Columbia; D, Daniels; E, Eldorado; F, Foss; H, Lynch; L, Lewis; R, Rainbow; S, Spider; U, Lower Curtis: Y, Yawning.

zone, annual accumulation-layer thickness is determined at the end of the ablation season using crevasse stratigraphy, snow pits, and probing, with a density of 200 points $/ \mathrm{km}^{2}$. Techniques used are those of Ostrem and Stanley (1969), who stated that for the best accuracy an acceptable density of measurements was 100 points $/ \mathrm{km}^{2}$. Crevasse stratigraphic measurements are conducted only in narrow, vertically walled crevasses that have distinguishable dirt bands. A measuring tape is lowered to the ablation surface of the past summer, marked by a $2-5 \mathrm{~cm}$ thick band of dirty firn or glacier ice, in several spots on each crevasse wall within a space of several meters. The average thickness is taken to be the accumulation-layer thickness at that point. The majority of accumulation measurements are made using this method; it is quick and accurate.

Two to four snow pits are completed on each glacier. The density and water equivalent of the snow-firn-pack is measured in two vertical profiles in each snow pit. Probing transects are used in regions with few crevasses, and are used to check the accuracy of crevasse stratigraphic measurements. A probing transect is started from bare glacier ice and then continued across the glacier. The rare ice lenses can be identified as sudden anomalous changes in depth that are of small areal extent. The probing instrument is a 1 in $[2.54 \mathrm{~cm}]$ diameter fiber-glass rod. Probing is used in snow depths of less than $2 \mathrm{~m}$, because of the difficulty in identifying the previous ablation surface at greater depths.

Comparison of results obtained from snow pits, crevasse stratigraphy, and probing indicates that the error in measurement of accumulation thickness is smallest using crevasse stratigraphy. Crevasses have previously been avoided because of danger and the false density readings, due to the snow-pack holding less liquid water and the different 
metamorphic processes that might take place on crevasse walls, altering the snow density. In this study, density readings from crevasse walls are not used. The narrow vertically walled crevasses are aproached on skis, and the skis are not removed during measurements.

The annual balance of the accumulation zone obtained each year is considered preliminary, until the accumulation-layer thickness is checked the following year. Standard maximum errors in depth measurement at any point are $\pm 0.05 \mathrm{~m}$ and in density determination $\pm 0.04 \mathrm{Mg} / \mathrm{m}^{3}$. The resulting error in mass-balance assessment for the accumulation zone is $\pm 0.10 \mathrm{~m}$. It should be noted that internal accumulation and superimposed ice are rarely present in the North Cascades (Meier and Tangborn, 1965; Pelto, 1987). The density of measurements in the accumulation is considerably greater than is typical, causing a smaller error. All errors calculated in the course of annual-balance measurements are for one standard deviation of the observed data values.

Below the snow line, ablation triangles are used to determine annual ablation. An ablation triangle consists of three stakes drilled into the glacier at $3 \mathrm{~m}$ intervals, forming an equilateral triangle. Two to four triangles are emplaced on each glacier. Each stake is a $3.3 \mathrm{~m}$ long white fiber-glass pole. Ablation triangles are placed in a sequence from regions first to lose their snow cover to regions where snow cover persists late into the ablation season. Each triangle is considered representative of annual ablation for parts of the ablation zone that are exposed at the same time. This method helps distinguish the changes in ablation rate as the summer progresses. Ablation measurements are made at nine points on the triangle periphery in late July and early August, recording the ablation during the first 3 months of the ablation season. Ablation measurements are repeated at the end of the ablation season, identifying total annual ablation. The stakes are drilled into the ice at the end of the ablation season, and again after the initial late July and early August ablation measurement. Downward melting of the drill hole and stake settling has not exceeded $0.10 \mathrm{~m} /$ year.

The error in annual ablation measurement is $\pm 0.30 \mathrm{~m}$, due to ice-density variations, low sampling density, and stake settling. In contrast to the accumulation zone, measurements in the ablation zone are sparser than typical hence, errors are greater. A mass-balance map is then compiled for each glacier (Fig. 2). The error in annualbalance calculation for an entire glacier is $\pm 0.15-0.20 \mathrm{~m}$, except during years of extreme ablation, when the error is slightly higher. A larger error in a year of high ablation is

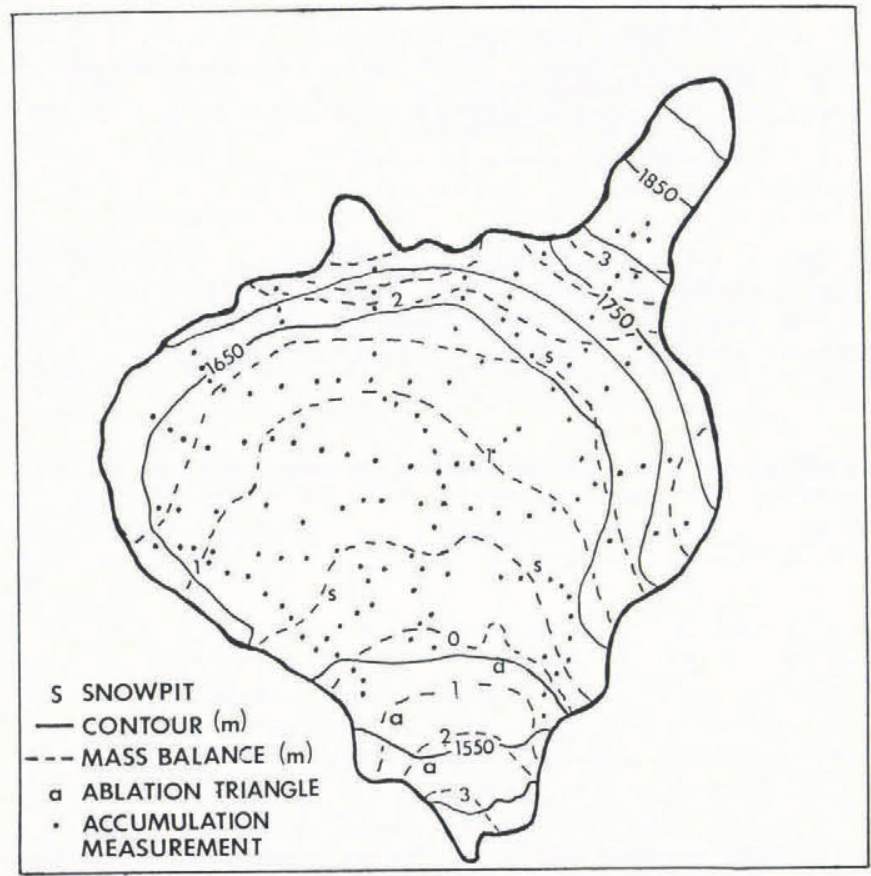

Fig. 2. Mass-balance map of Lower Curtis Glacier in 1986. Mass balance is contoured in meters of water equivalent. due to the increase in size of the ablation zone, a region where mass-balance measurements are the least accurate. The annual balance in $1984,1985,1986$, and 1987 for ten North Cascade glaciers is shown in Table I, and glacier locations are noted in Figure 1.

\section{AAR-ACTIVITY INDEX METHOD}

Knowing the mass balance of ten North Cascade glaciers still does not satisfactorily identify the mass balance of North Cascade glaciers as a whole, or their varying sensitivity to climatic conditions. For this reason, a simpler method of mass-balance determination was developed. The mass balance $(\mathrm{Bn})$ of a glacier is calculated using Equation (1):

$$
\mathrm{Bn}=\int_{z_{\mathrm{t}}}^{z_{\mathrm{u}}^{\mathrm{u}}} b(z) a(z) \mathrm{d} z
$$

where $a(z)$ is the area-altitude distribution, $b(z)$ is the balance gradient, $z_{\mathrm{t}}$ is the terminus elevation and $z_{\mathrm{u}}$ is the upper limit of the glacier. The area-altitude distribution is determined using standard planimetric techniques. The only unknown is the balance gradient.

The simpler mass-balance method relies on identification of the activity index and accumulation-area ratio (AAR) to determine the balance gradient. The AAR is the percentage of a glacier's total area above the equilbrium line (Meier and Post, 1962). The activity index is the balance gradient near the equilibrium line (Meier, 1962).

Because of the small size of North Cascade glaciers, the activity index actually represents the entire balance gradient. The activity index of North Cascade glaciers varies only slightly from year to year, as noted on South Cascade Glacier (Meier and Tangborn, 1965), and on each of the ten glaciers examined in this study (Pelto, 1987). The shape of the balance gradient is then constant but its position with respect to the mass-balance axis changes (Fig. 3). This indicates that spatially there is little annual variation in the annual-balance pattern for a given glacier. This attribute has been noted on many other alpine glacier systems in the Pamirs, Rocky Mountains, Alps, and Norway (Hoinkes, 1970; Östrem, 1973; Østrem, 1975; Kotlyakov and Krenke,

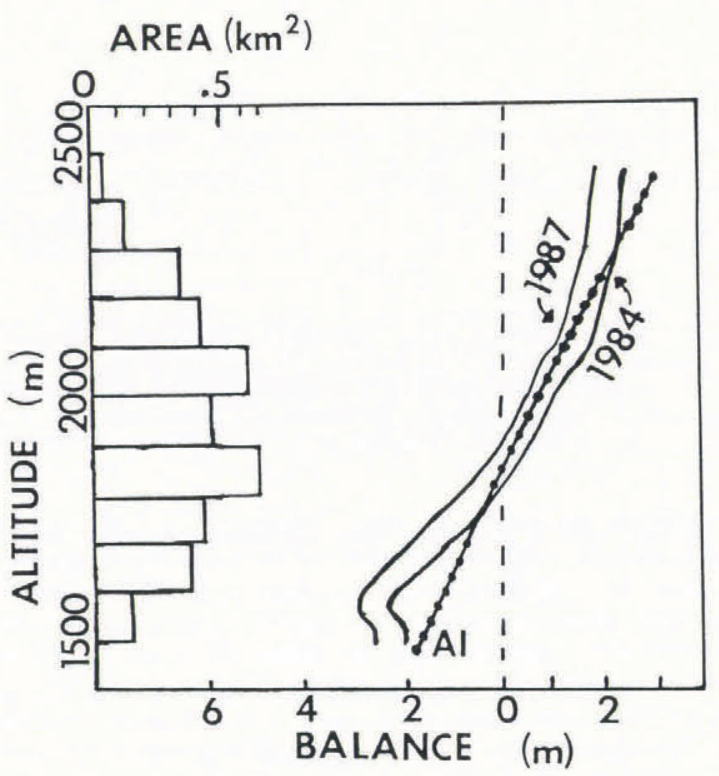

Fig. 3. The measured balance gradient of Rainbow Glacier on Mount Baker in 1984 and 1987. The perennially constant activity index (AI) is also shown. On the left is the area-altitude distribution. Mass balance of the glacier is the sum of the product of the area and mean balance within each $100 \mathrm{~m}$ elevation band. Mean balance values are selected from the activity-index line. 
TABLE I. THE ANNUAL BALANCE OF TEN NORTH CASCADE GLACIERS, FROM DIRECT FIELD MEASUREMENTS, IN METERS OF WATER EQUIVALENT. THE MINIMUM NUMBER OF ANNUAL MEASUREMENT SITES USED DURING THE 1984-87 PERIOD IS $n$

$\begin{array}{llllllr}\text { Glacier } & \text { Area } & 1984 & 1985 & 1986 & 1987 & n \\ & \mathrm{~km}^{2} & & & & \\ \text { Columbia } & 0.9 & +0.21 & -0.31 & -0.20 & -0.63 & 163 \\ \text { Daniels } & 0.5 & +0.11 & -0.51 & -0.36 & -0.87 & 97 \\ \text { Eldorado } & 1.4 & +0.25 & -0.14 & -0.02 & -0.45 & 204 \\ \text { Foss } & 0.7 & +0.51 & -0.69 & +0.12 & -0.38 & 146 \\ \text { Lewis } & 0.1 & +0.67 & -1.16 & -0.34 & -0.48 & 78 \\ \text { Lower Curtis } & 0.9 & +0.39 & -0.16 & -0.22 & -0.56 & 188 \\ \text { Lynch } & 0.8 & +0.33 & -0.22 & -0.07 & -0.20 & 112 \\ \text { Rainbow } & 1.5 & +0.58 & +0.04 & +0.20 & -0.26 & 159 \\ \text { Spider } & 0.1 & +1.12 & -0.63 & +0.30 & -1.15 & 38 \\ \text { Yawning } & 0.2 & +0.09 & -0.23 & -0.14 & -0.47 & 71\end{array}$

1982). This attribute would allow calculation of annual balance from measurement at a single representative point (Konovalov, 1987). Unfortunately, there is no single representative point. However, AAR observations can provide a representative network of mass-balance values along the snow line. With a known activity index, annual balance can then be determined.

The AAR is determined from gound and aerial photographs taken at the end of the ablation season, and keyed to topographic maps of the glacier. The AAR has been observed annually on 47 North Cascade glaciers, during the 1984-87 period. The activity index is determined for each of the 47 glaciers by observing the rate of rise with time of the snow line, during the ablation season, in comparison with measured snow depth above the snow line. When tested on Columbia and Lynch Glaciers against field measurements, this method gave excellent agreement (Fig. 4). The annual-balance gradient is then accurately represented by the activity index (Figs 3 and 4 ).

The balance gradient used in Equation (1) to calculate mass balance is then the observed activity index, referenced with respect to the altitude and mass-balance axes at the snow line, using AAR observations. The activity index is monitored annually to ascertain its consistency. On 43 of

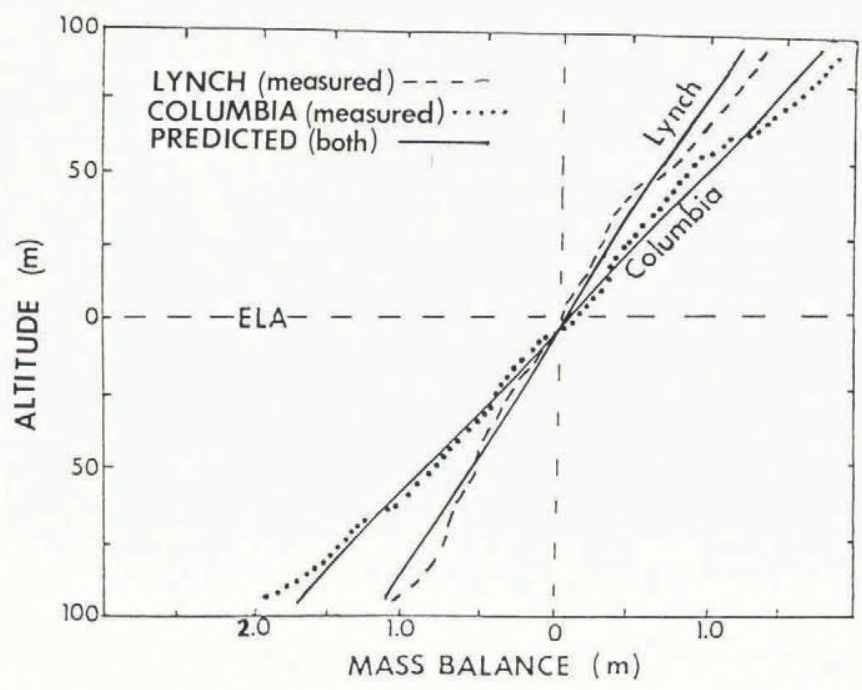

Fig. 4. The predicted activity index versus measured balance gradient near the snow line on Columbia and Lynch Glaciers in 1986. the 47 glaciers, the activity index has varied less than $10 \%$ from minimum to maximum values during the 4 year period. If the activity index is demonstrated to be constant, then only observation of the AAR will be neccesary to calculate annual balance.

The annual balance (bn) is calculated for each glacier using Equation (2), where $A_{\mathrm{t}}$ is the total area of the glacier:

$$
\mathrm{bn}=\frac{\mathrm{Bn}}{A_{\mathrm{t}}} \text {. }
$$

This method is tested against the annual balance of the ten glaciers, where annual balance is directly measured. Comparison of the results indicates an error of $\pm 0.23-0.28 \mathrm{~m}$ of water equivalent (Fig. 5), and that the error is random.

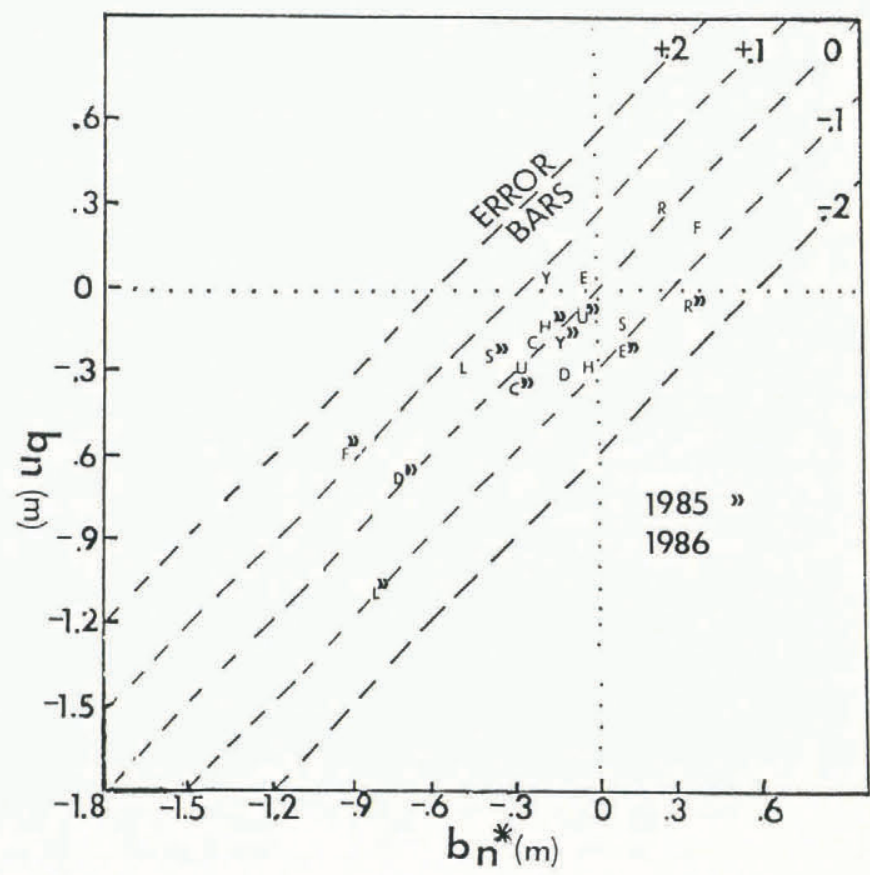

Fig. 5. The measured annual balance (bn) of ten North Cascade glaciers in 1985 and 1986, compared to the predicted annual balance (bn), obtained using the activity-index method. Dashed lines represent errors in annual-balance prediction. $C$, Columbia; $D$, Daniels; $E$, Eldorado; F, Foss; H, Lynch; L, Lewis; R, Rainbow; $S$, Spider; U, Lower Curtis; Y, Yawning. 


\section{RECENT GLACIER BEHAVIOR}

North Cascade glaciers retreated rapidly during the first half of the present century (Hubley, 1956). The retreat ended and a general advance began in the 1950s, due to an increase in winter precipitation and a decrease in ablation-season temperature beginning in 1944 (Hubley, 1956). The majority of North Cascade glaciers advanced during the 1955-65 period and mantained an advanced position until 1976. Between 1944 and 1974, North Cascade glaciers were near mass-balance equilibrium (Tangborn, 1980). Since 1977, ablation-season temperature has been $1.1^{\circ} \mathrm{C}$ above, and winter precipitation $15 \%$ below, the $1920-80$ mean in the North Cascade region. The result has been moderate negative mass balances and retreat of 42 of the 47 glaciers observed in this study.

\section{CLIMATIC CONTROLS OF MASS BALANCE}

The mass balance of North Cascade glaciers is primarily determined by winter precipitation (1 October-30 April), ablation-season temperature (1 May-30 September), and summer cloud cover (1 July-1 September) (Tangborn, 1980). The freezing level during precipitation events in May and October has a significant effect on winter accumulation for many glaciers. The freezing level is the line above which precipitation falls as snow during each precipitation event.

Observation of the mass-balance records obtained from the 47 glaciers indicates that North Cascade glaciers presently fall into six distinct climatic sensitivity groups, based on their differing sensitivity to four controlling climatic parameters (Table II). The ranking of sensitivity to each climatic parameter is still qualitative, and is based on analysis of the annual-balance record versus the variation of the four climatic parameters. The annual-balance record of each glacier can be accurately explained by only one ranking scheme of the climatic parameters. A glacier's sensitivity to each climatic parameter is determined by its geographic location and topographic position. Each sensitivity type is then associated with fairly specific geographic and topographic characteristics: degree of radiational shading, orientation, altitude with respect to the glaciation threshold, and accumulation sources (Porter, 1977). Accumulation sources are direct snowfall, avalanching, and wind drifting. Table III shows a preliminary assessment of the topographic and geographic characteristics of each sensitivity type. Identification of the sensitivity type of a North Cascade glacier should provide a framework for determining the regimen of each North Cascade glacier without examining each glacier in detail. The observed behavior could then be understood in a climatic context. Table IV displays the annual balance for each climatic sensitivity type during the 1984-87 period.

During the past decade in the North Cascades the larger a glacier's winter balance, the healthier the glacier. High-altitude accumulation zones, multiple accumulation sources, and a northward orientation are all associated with larger winter balances.

The glaciers showing the greatest response mass balance to the recent climatic fluctuations are those most sensitive to changes in winter snowfall. These glaciers have none or one of the large winter-balance factors. The rise in ablation-season temperature has had a lesser effect on glacier mass balance. Mass-balance and snow-pack measurements indicate a greater reduction in snowfall at lower altitudes than at higher altitudes. The greatest reduction in snowfall has been south of Holden and east of the Cascade Crest (Fig. 1).

TABLE II. RANKING OF IMPORTANCE OF CLIMATIC PARAMETERS AFFECTING GLACIER MASS BALANCE FOR EACH CLIMATIC SENSITIVITY GROUP. WINTER PRECIPITATION (WP), ABLATION-SEASON TEMPERATURE (AT), SUMMER CLOUD COVER (SC), AND FREEZING LEVEL DURING PRECIPITATION EVENTS IN MAY AND OCTOBER (FL)

\begin{tabular}{llllll} 
Group & \multicolumn{2}{c}{ Primary } & ------ Secondary & Example \\
1 & SC & WP & AT & FL & Daniels Glacier \\
2 & WP & SC & AT & & Eldorado Glacier \\
3 & WP & AT & SC & & Yawning Glacier \\
4 & AT and & WP & FL & SC & Columbia Glacier \\
5 & WP & AT & SC & FL & Rainbow Glacier \\
6 & AT & WP & SC & FL & Lewis Glacier
\end{tabular}

TABLE III. A CLASIFICATION OF THE CLIMATIC SENSITIVITY GROUPS BY GLACIER ORIENTATION, IN DEGREES READING CLOCKWISE FROM LEFT $\mathrm{N}=0^{\circ}, \mathrm{S}=180^{\circ}$; DEGREE OF RADIATIONAL SHADING, ALTITUDE WITH RESPECT TO THE LOCAL GLACIATION THRESHOLD, AND ACCUMULATION SOURCES RATED IN ORDER OF IMPORTANCE (AV, AVALANCHING; DS, DIRECT SNOWFALL; WD, WIND DRIFTING)

$\begin{array}{lllll}\text { Group } & \begin{array}{l}\text { Glacier } \\ \text { orientation }\end{array} & \text { Shading } & \text { Altitude } & \text { Accumulation sources } \\ 1 & 075-285 & \text { Poor } & \text { Average } & \text { DS } \\ 2 & \text { Any } & \text { Poor } & \text { High } & \text { DS } \\ 3 & 285-075 & \text { Good } & \text { Average } & \text { DS } \\ 4 & 300-060 & \text { Good } & \text { Low } & \text { DS and WD or AV } \\ 5 & \text { Any } & \text { Fair } & \text { Average }+ & \text { DS, WD, and AV } \\ 6 & 270-090 & \text { Fair } & \text { Average } & \text { DS and AV }\end{array}$


TABLE IV. THE MEAN ANNUAL BALANCE (m) OF 47 NORTH CASCADE GLACIERS AND THE MEAN ANNUAL BALANCE (m) FOR EACH OF THE SIX CLIMATIC SENSITIVITY GROUPS, DURING THE YEARS 1984, 1985, 1986, AND 1987 (PRELIMINARY). THE NUMBER OF GLACIERS $(n)$ OF EACH SENSITIVITY GROUP OBSERVED IN THIS STUDY IS ALSO NOTED

Mean annual balance

$\begin{array}{llllllll}\text { Year } & \text { Group } 1 & \text { Group 2 } & \text { Group 3 } & \text { Group 4 } & \text { Group 5 } & \text { Group 6 } & \text { Mean } \\ 1984 & +0.20 & +0.30 & +0.40 & +0.55 & +0.40 & +0.05 & +0.35 \\ 1985 & -0.85 & -0.65 & -0.40 & -0.50 & -0.25 & -1.00 & -0.50 \\ 1986 & -0.50 & -0.60 & -0.20 & -0.35 & -0.10 & -0.40 & -0.30 \\ 1987 & -0.60 & -0.75 & -0.50 & -0.85 & -0.40 & -0.80 & -0.65 \\ 1984-87 & -0.43 & -0.45 & -0.18 & -0.27 & -0.09 & -0.55 & -0.30 \\ n & 6 & 7 & 10 & 7 & 11 & 6 & 47\end{array}$

\section{CONCLUSIONS}

The primary goal of this project was to establish a system for annually monitoring the mass balance on numerous North Cascade glaciers. This task has been completed on a total of 47 glaciers. The objective is reasonable accuracy on numerous glaciers but not strict accuracy on a few.

It is evident that the annual balance of a North Cascade glacier can be determined with an accuracy of $\pm 0.23-0.28 \mathrm{~m}$ by observation of the annual AAR, the activity index, and area-altitude distribution. The AAR can be quickly determined from aerial and ground photographs at the end of the ablation season (Meier and Post, 1962). Examination of a glacier's sensitivity to meteorologic conditions indicates that six different glacier climatic sensitivity groups exist in the North Cascades. Annual mass balances are similar for each sensitivity group member in a specific region.

The mean annual balance of North Cascade glaciers during the 1984-87 period was $-0.33 \mathrm{~m} / \mathrm{a}$. Since 1976, there has been a strong negative mass-balance regime in the North Cascades. This trend is due to an increase in persistence of anticyclonic conditions throughout the year (Pelto, 1987).

Braithwaite (1984) posed the question "can the mass balance of a glacier be estimated from its equilibrium-line position?" The answer for North Cascade glaciers is yes, if the activity index and area-altitude distribution are known.

The next goal of the North Cascade Glacier-Climate Project is to determine the climatic sensitivity of each North Cascade glacier and to quantify this relationship. The annual balance of North Cascade glaciers can then be related to synoptic climatology in a quanititative manner.

\section{REFERENCES}

Braithwaite, R.J. 1984. Can the mass balance of a glacier be estimated from its equilibrium-line altitude? Journal of Glaciology, 30(106), 364-68.

Hoinkes, H. 1970. Methoden und Möglichkeiten von Massenhaushaltsstudien auf Gletschern. Zeitschrift für Gletscherkunde und Glazialgeologie, 6(1-2), 37-90.

Hubley, R.C. 1956. Glaciers of the Washington Cascade and Olympic Mountains; their present activity and its relation to local climatic trends. Journal of Glaciology, 2(19), 669-74.

Konovalov, V.G. 1987. Methods of calculation and remote-sensing measurements for the spatial distribution of glacier annual mass balances. Journal of Glaciology, 33(114), 212-17.

Kotlyakov, V.M., and Krenke, A.N. 1982. Investigations of the hydrological conditions of alpine regions by glaciological methods. International Association of Hydrological Sciences Publication 138 (Symposium at Exeter 1982 - Hydrological Aspects of Alpine and High-Mountain Areas), 31-42.

Meier, M.F. 1962. Proposed definitions for glacier mass budget terms. Journal of Glaciology, 4(33), 252-63.

Meier, M.F., and Post, A. 1962. Recent variations in mass net budgets of glaciers in western North America. International Association of Scientific Hydrology Publication 58 (Symposium of Obergurgl 1962 - Variations of the Regime of Existing Glaciers), 63-77.

Meier, M.F., and Tangborn, W.V. 1965. Net budget and flow of the South Cascade Glacier, Washington. Journal of Glaciology, 5(41), 547-66.

Östrem, G. 1973. The transient snowline and glacier mass balance in southern British Columbia and Alberta, Canada. Geografiska Annaler, 55A(2), 93-106.

Østrem, G. 1975. ERTS data in glaciology - an effort to monitor glacier mass balance from satellite imagery. Journal of Glaciology, 15(73), 403-15.

Ostrem, G., and Stanley, A. 1969. Glacier mass balance measurements. Ottawa, Canadian Department of Energy, Mines and Resources; Oslo, Norwegian Water Resource and Electricity Board.

Pelto, M.S. 1987. The mass balance of North Cascade glaciers and climatic implications. International Association of Hydrological Sciences Publication 168 (Symposium at Vancouver 1987 - The Influence of Climate Change and Climatic Variability on the Hydrologic Regime and Water Resources), 163-71.

Porter, S.C. 1977. Present and past glaciation threshold in the Cascade Range, Washington, U.S.A.: topographic and climatic controls, and paleoclimatic implications. Journal of Glaciology, 18(78), 101-16.

Post, A., Richardson, D., Tangborn, W.V., and Rosselot, F.L. 1971. Inventory of glaciers in the North Cascades, Washington. U.S. Geological Survey. Professional Paper 705-A.

Tangborn, W.V. 1980. Two models for estimating climate-glacier relationships in the North Cascades, Washington, U.S.A. Journal of Glaciology, 25(91), 3-21.

Tangborn, W.V., Krimmel, R.M., and Meier, M.F. 1975. A comparison of glacier mass balance by glaciological, hydrological and mapping methods, South Cascade Glacier, Washington. International Association of Hydrological Sciences Publication 104 (General Assembly of Moscow 1971 - Snow and Ice), 185-96.

Yarnal, B. 1984. Relationships between synoptic-scale atmospheric circulation and glacier mass balance in south-western Canada during the International Hydrological Decade, 1965-74. Journal of Glaciology, 30(105), 188-98. 